\title{
HYPERBARIC COLD STORAGE: PRESSURE AS AN EFFECTIVE TOOL FOR EXTENDING THE SHELF-LIFE OF REFRIGERATED MACKEREL (Scomber scombrus, L.)
}

\author{
Otero, L. ${ }^{1}$, Pérez-Mateos, M., Holgado, F., Márquez-Ruiz, G., and López-Caballero, M. E.
}

Institute of Food Science, Technology and Nutrition (ICTAN-CSIC). c/ José Antonio Novais, 10, 28040 Madrid, Spain

\section{ABSTRACT}

The efficacy of hyperbaric cold storage for preserving lean fish has been recently demonstrated but, lamentably, no data exist for fatty fish. To evaluate the effect of hyperbaric cold storage on the shelf-life and quality of fatty fish, we stored Atlantic mackerel fillets at $5{ }^{\circ} \mathrm{C}$, both at atmospheric pressure and at $50 \mathrm{MPa}$. After 12 days of hyperbaric storage, microbial counts were similar or even lower than those of control samples at day 0 and no significant lipid degradation was observed. By contrast, increased microbial counts and significant lipid hydrolysis were detected in the samples stored at atmospheric pressure. Moreover, even though the protein profile was significantly altered during hyperbaric storage, most fish-quality indicators ( $\mathrm{pH}$, TVB-N, drip loss, water holding capacity, and hardness after cooking) were better preserved in the mackerel samples stored at $50 \mathrm{MPa}$. These results clearly prove that hyperbaric cold storage was more efficient than conventional refrigeration for the preservation of Atlantic mackerel fillets.

Industrial relevance: Long-term preservation of fatty fish is a challenge for the seafood industry mainly due to lipid degradation that can rapidly reduce fish quality. If effective against lipid degradation, hyperbaric cold storage could be an interesting technology to preserve fish and fish products. The increased cost resulting from hyperbaric storage should be overcome by an extended shelf-life of a high-quality product.

Keywords: hyperbaric storage; cold storage; high pressure; fatty-fish preservation; Atlantic mackerel

\section{INTRODUCTION}

Hyperbaric cold storage is a preservation method that consists in storing food at high pressure (usually below $100 \mathrm{MPa}$ ) and low temperature for time periods of some days, weeks, or months. Even though this technique was first proposed 40 years ago (Charm, Longmaid, \& Carver, 1977), only a few studies were conducted until this century probably due to the technical difficulties in building high-pressure storage equipment at that time. Nevertheless, after the successful implantation of high-pressure processing in the food industry, the interest on

\footnotetext{
${ }^{1}$ Corresponding author: Tel.: +34 9154923 00; fax: +34 915493627 .

E-mail address: I.otero@ictan.csic.es (L. Otero).
} 
hyperbaric storage, both at room and at low temperature, has reappeared. Thus, several papers that prove the industrial viability of the hyperbaric method (Bermejo-Prada, Colmant, Otero, \& Guignon, 2017) and its efficiency in extending the shelf-life of different food products have been recently published (Bermejo-Prada, López-Caballero, \& Otero, 2016; Duarte et al., 2017; Fidalgo, Lemos, Delgadillo, \& Saraiva, 2018; Otero, Pérez-Mateos, \& López-Caballero, 2017).

Hyperbaric cold storage, at pressures of $50 \mathrm{MPa}$ and lower, has been shown to be more efficient than conventional refrigeration for the preservation of lean fish (Charm et al., 1977; Otero et al., 2017). Pressures larger than $100 \mathrm{MPa}$ are not recommended because considerable protein denaturation can occur and affect some quality properties of fish, such as texture, color, or water-holding capacity, among others (Matser, Stegeman, Kals, \& Bartels, 2000; Truong, Buckow, Stathopoulos, \& Nguyen, 2015). Otero et al. (2017) reported that, unlike how it occurs during conventional refrigeration, storage at $50 \mathrm{MPa}$ and $5{ }^{\circ} \mathrm{C}$ completely inhibited the growth of total aerobic mesophiles and Enterobacteriaceae in hake loins for 7 days. Moreover, even though the shear resistance and whiteness of the raw samples increased during storage at $50 \mathrm{MPa}$, the sensorial analysis could only find moderate differences between the cooked samples before and after hyperbaric storage.

However, the efficacy of hyperbaric cold storage in preserving fatty fish has not yet been assessed. Long-term preservation of fatty fish is still nowadays a challenge for the seafood industry. The presence of relatively large amounts of polyunsaturated fatty acids (PUFAs), although with recognized benefits for health, is an important obstacle for fish preservation due to their instability in the presence of pro-oxidant molecules such as haemoglobin and metallic ions also present in fish muscles. Thus, during both chilled and frozen storage, lipid hydrolysis and oxidation occur in fatty fish species and these degradative reactions can rapidly reduce the fish quality by causing rancidity, off-flavors, color and taste changes, texture degradation, and health hazards such as the formation of highly reactive radicals (Ashie, Smith, \& Simpson, 1996; Huss, 1995; Medina-Meza, Barnaba, \& Barbosa-Cánovas, 2014). For this reason, great efforts are currently directed by many food researchers to look for new preservation techniques able to reduce lipid degradation during storage of fatty fish (Fattouch, Sadok, Raboudi-Fattouch, \& Slama, 2008; Karoui \& Hassoun, 2017; Vázquez, Torres, Gallardo, Saraiva, \& Aubourg, 2013).

Pressure appears to be an e promising tool for reducing lipid decay during fish storage. Thus, several authors have observed that a short pressure pretreatment allows to inhibit lipid oxidation and/or hydrolysis in different fatty fish species during their subsequent chilled (Ohshima, Nakagawa, \& Koizumi, 1992; Senturk \& Alpas, 2013) or frozen storage (M. Pazos et al., 2015; Torres, Vázquez, Saraiva, Gallardo, \& Aubourg, 2013; Vázquez et al., 2013). However, the opposite has also been reported (Ortea, Rodríguez, Tabilo-Munizaga, Pérez-Won, \& Aubourg, 2010; Rode \& Hovda, 2016; Yagiz, Kristinsson, Balaban, \& Marshall, 2007) and, therefore, data in the literature are apparently controversial. Pressure effects on lipid stability seem to strongly depend on fish species, type of muscle, pressure level, and holding time (Medina-Meza et al., 2014; Truong et al., 2015) and, in general, the larger the pressure and the longer the holding time, the larger the lipid degradation (Medina-Meza et al., 2014; Ohshima et al., 1992; Sequeira-Munoz, Chevalier, LeBail, Ramaswamy, \& Simpson, 2006).

In hyperbaric storage, pressure levels applied to food products are relatively low, but holding times are very long. Lamentably, data on the effect of pressure treatments longer than $60 \mathrm{~min}$ on lipid degradation hardly exist in the literature. Therefore, there is an urgent need to evaluate how long periods under pressure can affect lipid stability in fatty fish. Recently, Fidalgo et al. (2018) evaluated lipid oxidation in salmon fillets stored at different pressure and temperature conditions for 10 days. They observed larger peroxide values and levels of thiobarbituric acidreactive substances (TBARS) in the samples kept at 50-75 $\mathrm{MPa}$ and room temperature than in those conventionally cold stored $\left(0.1 \mathrm{MPa} / 4{ }^{\circ} \mathrm{C}\right)$. Unfortunately, to the best of our knowledge, no 
data exist for fatty fish stored at high pressure and low temperature for so long periods. It is well-known that many degradative reactions implied in lipid decay are significantly retarded at low temperature (Ashie et al., 1996; Huss, 1995). Therefore, hyperbaric cold storage, that combines high pressure and low temperature, could be particularly useful for preserving fatty fish.

To evaluate the effect of hyperbaric cold storage on the shelf-life and quality of fatty fish, we stored Atlantic mackerel fillets at $5{ }^{\circ} \mathrm{C}$ for 12 days, both at atmospheric pressure and at $50 \mathrm{MPa}$. After storage, we compared the microbial load, the lipid and protein fractions, and several fishquality indicators, both before and after cooking, in all the samples.

The current study provides valuable new data for evaluating the ability of hyperbaric storage to extend the shelf-life of refrigerated foods. Moreover, it also increases the knowledge on the effects of high pressure on food matrices and sets out new questions for future research in this area.

\section{MATERIALS AND METHODS}

\subsection{Sample}

Before each experiment, a batch of butterfly fillets of Atlantic mackerel (Scomber scombrus, L.), caught in the Northeast Atlantic Ocean, was acquired in a specialized market. The fillets were $24.6 \pm 0.3 \mathrm{~cm}$ in length and they weighed $228.5 \pm 5.7 \mathrm{~g}$.

\subsection{Cold storage experiments}

Just after receiving the mackerel fillets at the laboratory, the batch was divided into three groups. One group was immediately analyzed to characterize the control sample (C) at day 0 , while the fillets of the other two groups were individually vacuum packaged in polyethylene bags and stored at $5 \pm 2{ }^{\circ} \mathrm{C}$, either at $50 \pm 2 \mathrm{MPa}$ (hyperbaric cold storage, HP_CS) or at atmospheric pressure (AP_CS), for 12 days.

Storage experiments under pressure were carried out in a pilot-plant high-pressure storage system (model SV1, Institute of High Pressure Physics, Unipress Equipment Division, Poland). It was composed of two high-pressure stainless-steel vessels $(100 \mathrm{~mm}$ internal diameter, 130 $\mathrm{mm}$ height and a working volume of $1 \mathrm{~L}$ ) to lodge the samples during storage, two control terminals, and a high-pressure pump. A mixture of propylene glycol and water (44\% v/v) was used as compressing fluid. Each high-pressure vessel was located in an individual thermostatic chamber. The temperature during storage was monitored both inside the pressure vessels and at the thermostatic chambers by $4 \mathrm{~T}$-type thermocouples. The pressure in each vessel was monitored by a pressure transducer (0-400 MPa, SH-1, WIKA, Germany). All sensor measurements were recorded every $30 \mathrm{~s}$ by a data acquisition system (MW100 Data Acquisition Unit, Yokogawa Electric Corporation, Tokyo, Japan).

Storage experiments at atmospheric pressure were performed at the same thermostatic chambers where the high-pressure vessels were located. AP_CS samples were immersed in a tank filled with a mixture of propylene glycol and water $(44 \% \mathrm{v} / \mathrm{v})$ and stored in the dark to mimic exactly the same conditions as those of hyperbaric experiments, except the pressure level.

All the storage experiments were performed in triplicate and, in each experiment, 3 C, 3 AP_CS, and 3 HP_CS fillets were analyzed. 


\subsection{Microbial stability during storage}

Samples were analyzed as described previously by Otero et al. (2017). Briefly, $10 \mathrm{~g}$ of Atlantic mackerel muscle was collected in a vertical laminar-flow cabinet (mod. AV 30/70 Telstar, Madrid, Spain) and placed in a sterile plastic bag (Sterilin, Stone, Staffordshire, UK) with $90 \mathrm{~mL}$ of buffered $0.1 \%$ peptone water (Oxoid, Basingstoke,UK). After 1-minute processing in a Stomacher blender (model Colworth 400, Seward, London, UK), ten-fold serial dilutions were prepared in buffered peptone water and duplicates of the dilutions were plated on the appropriate medium, according to the procedures as follows: total viable bacteria (TVB) on spread plates of Iron Agar (Scharlab, Barcelona, Spain) $1 \% \mathrm{NaCl}$ incubated at $15^{\circ} \mathrm{C}$ for 3 days; $\mathrm{H}_{2} \mathrm{~S}$-producing organisms, as black colonies, on pour plates of Iron Agar incubated at $15^{\circ} \mathrm{C}$ for 3 days; luminescent bacteria on spread plates of Iron Agar $1 \% \mathrm{NaCl}$ incubated at $15{ }^{\circ} \mathrm{C}$ for 5 days; total aerobic mesophiles on pour plates of Plate Count Agar, PCA (Oxoid) incubated at 30 ${ }^{\circ} \mathrm{C}$ for $72 \mathrm{~h}$; Pseudomonas on spread plates of Pseudomonas Agar Base (Oxoid) with added CFC (Cetrimide, Fucidine, Cephalosporine) supplement for Pseudomonas spp. (Oxoid) incubated at $25^{\circ} \mathrm{C}$ for $48 \mathrm{~h}$; Enterobacteriaceae on double-layered plates of Violet Red Bile Glucose agar (VRBG, Oxoid) incubated at $30^{\circ} \mathrm{C}$ for $48 \mathrm{~h}$; lactic acid bacteria on double-layered plates of MRS Agar (Oxoid) incubated at $30^{\circ} \mathrm{C}$ for $72 \mathrm{~h}$; and anaerobic sulphite-reducing bacteria (Clostridium perfringens) on double-layered plates of Tryptose Sulfite Cycloserine Agar, TSC (bioMèrieux, Marcy l'Etoile, France) incubated at $37^{\circ} \mathrm{C}$ for $48 \mathrm{~h}$. Plate counts were expressed as the decimal logarithm of colony-forming units (CFU) per gram of mackerel muscle $\left(\log _{10} \mathrm{CFU} \cdot \mathrm{g}^{-1}\right)$. The detection limit was $1 \log _{10} \mathrm{CFU} \cdot \mathrm{g}^{-1}$ in pour plates and $2 \log _{10} \mathrm{CFU} \cdot \mathrm{g}^{-1}$ in spread plates.

\subsection{Lipid stability during storage}

Lipids in the fish muscle were extracted according to the method described by Bligh and Dyer (1959) by using a dichloromethane-methanol mixture (1:1, v/v) as solvent. In each sample, the lipid extraction was performed in duplicate and the results were expressed as $\mathrm{g}$ lipid/100 $\mathrm{g}$ fish muscle. After extraction, all the lipid extracts were stored at $-80^{\circ} \mathrm{C}$ until analysis.

The fatty acid composition was determined in the extracted lipids by analysis of the fatty acid methyl esters (FAME). FAME were prepared according to the AOCS method (IUPAC, 1992a, 1992b) using a base-catalyzed transesterification followed by a boron-trifluoride-catalyzed esterification. FAME were then analyzed on a HP-6850 Series chromatograph (Agilent Technologies, Palo Alto, CA, USA) equipped with a split/splitless injector and a flame ionization detector. FAME were separated using a HP Innowax polyethylene glycol capillary column (30 m length $\times 0.25 \mathrm{~mm}$ i.d. $\times 0.25 \mu \mathrm{m}$ film thickness; Agilent Technologies, Palo Alto, CA, USA). The injector and detector temperatures were $250{ }^{\circ} \mathrm{C}$. The oven temperature was set initially at 180 ${ }^{\circ} \mathrm{C}$ and held for $2 \mathrm{~min}$, then raised to $230^{\circ} \mathrm{C}$ at a rate of $3{ }^{\circ} \mathrm{C} / \mathrm{min}$ and held for $20 \mathrm{~min}$. The split ratio at the injector was 1:40 and hydrogen was the carrier gas at a flow rate of $1 \mathrm{~mL} / \mathrm{min}$. The sample volume injected was $1 \mu \mathrm{L}$. Polyene index was calculated as follows:

$$
\text { Polyene index }=\frac{[\text { Eicosapentanoic acid }]+[\text { Docosahexanoic acid }]}{[\text { Stearic acid }]} \times 100
$$

The quantitative determination of polymerization compounds (triacylglycerol dimers and higher oligomers) and hydrolytic compounds (diacylglycerols, monoacylglycerols, and free fatty acids) 
was carried out by high-performance size-exclusion chromatography (HPSEC) according to the IUPAC method (IUPAC, 1992b). Lipid extracts were dissolved in tetrahydrofuran $(50 \mathrm{mg} / \mathrm{mL})$ for direct analysis by HPSEC. An HPSEC chromatographic system consisting on a 7725i Rheodyne injector with a 10- $\mu \mathrm{L}$ sample loop (Waters, Milford, MA, USA), a Waters 510 pump (Waters, Milford, MA, USA), and a Waters 2414 refractive index detector (Waters, Milford, MA, USA) was used. The separation was performed by using two 100 and $500 \AA$ PLgel columns packed with porous, highly cross-linked styrene-divinylbenzene copolymers $(25 \mathrm{~cm}$ length $\times$ $0.77 \mathrm{~cm}$ i.d. $\times 5 \mu \mathrm{m}$ film thickness; Agilent Technologies, Palo Alto, CA, USA) connected in series. Tetrahydrofuran was used as the mobile phase at a flow of $1 \mathrm{~mL} / \mathrm{min}$. An Agilent 35900E Interface and HP ChemStation software (Agilent Technologies, Palo Alto, CA, USA) were used for data acquisition. The groups of compounds eluting under these conditions were: triacylglycerol (TG) oligomers (TGO), TG dimers (TGD), TG monomers (TGM), diacylglycerols (DG), monoacylglycerols (MG) and free fatty acids (FFA) in this order of elution. According to the official method, the same response factor was assumed for all the peaks and, consequently, polymerization and hydrolytic compounds were expressed as weight percentage. In each sample, all the determinations were performed in duplicate and then averaged.

\subsection{Protein stability during storage}

The extraction of sarcoplasmic and myofibrillar proteins from the mackerel samples was performed according to the protocol described by M. Pazos et al. (2015). In brief, $0.5 \mathrm{~g}$ of fish muscle was homogenized in $10 \mathrm{~mL}$ of Tris buffer (10 mM Tris- $\mathrm{HCl}, \mathrm{pH} 7.2)$, containing $5 \mathrm{mM}$ protease inhibitor (phenylmethylsulfonyl fluoride, PMFS). This homogenate was centrifuged at $40000 \times g$ and $4{ }^{\circ} \mathrm{C}$ for 20 min (Sorvall CombiPlus ultracentrifuge, DuPont, Wilmington, DE, USA) and the sarcoplasmic protein fraction was obtained from the supernatant. The pellet was then homogenized with a saline solution $(0.6 \mathrm{M} \mathrm{NaCl}, 10 \mathrm{mM}$ Tris buffer, $5 \mathrm{mM}$ PMFS, pH 7.2) and centrifuged at $4500 \times g$ and $4{ }^{\circ} \mathrm{C}$ for 20 min (Sorvall Evolution RC, model 728311, Thermo Electron Corporation, Asheville, NC, USA) to obtain the myofibrillar protein fraction. The protein concentration of the sarcoplasmic and myofibrillar fractions was determined by using the standard microplate procedure (Bio-Rad Protein Assay Dye Reagent Concentrate; Bio-Rad Laboratories, Hercules, CA, USA) based on the method developed by Bradford (1976). The sarcoplasmic and myofibrillar protein solubilities were expressed as grams of soluble protein in the respective fractions per $100 \mathrm{~g}$ of fish muscle.

The protein profiles in the sarcoplasmic and myofibrillar fractions were visualized by 1D SDSPAGE electrophoresis. To do so, both protein fractions were 1:1 diluted in 2X SDS-PAGE Laemmli sample buffer $(65.8 \mathrm{mM}$ Tris- $\mathrm{HCl}, \mathrm{pH}$ 6.8, $26.3 \%$ glycerol, $2.1 \%$ SDS, $0.01 \%$ bromophenol blue; Bio-Rad Laboratories, Hercules, CA, USA) and heated at $70{ }^{\circ} \mathrm{C}$ for $10 \mathrm{~min}$. Both protein fractions were then applied at $4.5 \mu \mathrm{g}$ per lane on a $4-20 \%(\mathrm{w} / \mathrm{v})$ polyacrylamide gel and run at $200 \mathrm{~V}$ for $30 \mathrm{~min}$. Standard proteins of known molecular weight (Unstained Precision Plus Protein ${ }^{\mathrm{TM}}$, Bio-Rad Laboratories, Hercules, CA, USA) were used to estimate the molecular weights of the proteins in the mackerel samples. Immediately, after the electrophoretic separation, the SDS-PAGE gels were activated by UV exposure using a transilluminator (Molecular Image ${ }^{\circledR}$ ChemiDoc ${ }^{\mathrm{TM}}$ XRS+, model Universal Hood II with Image Lab $^{\mathrm{TM}}$ Software v5.1, Bio-Rad Laboratories, Hercules, CA, USA).

\subsection{Effects of storage on fish-quality indicators}

Several indicators of fish quality were evaluated in both raw and cooked mackerel fillets. Thus, $\mathrm{pH}$, total volatile basic-nitrogen content, drip loss after storage, water-holding capacity, 
firmness, and color were determined in the raw samples, while cooking loss, firmness, and color were measured in the cooked fillets. Before cooking, the samples were packed in vegetal paper and then they were cooked in a saturated steam oven (Rational, Combi-Master CM 6, Croßküchentechnik $\mathrm{GmbH}$, Landsberg a. Lech, Germany) at $100{ }^{\circ} \mathrm{C}$ for $10 \mathrm{~min}$.

\subsection{1. $\mathrm{pH}$}

$\mathrm{pH}$ was measured in fish homogenates ( $5 \mathrm{~g}$ of fish flesh in $50 \mathrm{~mL}$ of distilled water) at room temperature with a pH meter ( $\mathrm{pH}$-Burette 24 1S equipped with a pH 5021 electrode and a C.A.T. 5531 temperature sensor, Crison Instruments, Barcelona, Spain). For each sample, two homogenates were obtained and the corresponding $\mathrm{pH}$ measurements were averaged.

\subsubsection{Total volatile basic-nitrogen (TVB-N)}

TVB-N was determined according to the steam distillation method (Community, 2005) with some slight modifications. To do so, $10 \mathrm{~g}$ of fish was homogenized with $90 \mathrm{~mL}$ of $6 \%$ perchloric acid for $1 \mathrm{~min}$. The homogenates were then filtered through a Whatman no. 1 filter paper and brought to $100 \mathrm{~mL}$. Then, $50 \mathrm{~mL}$ of this extract was transferred to the distillation tube with 5 drops of phenolphthalein and $9.5 \mathrm{~mL}$ of $20 \% \mathrm{NaOH}$ and the steam distillation began immediately. The distillation outflow tube was submerged in a receiver with $100 \mathrm{~mL}$ of $3 \%$ boric acid and 3 drops of the indicator solution $(0.01 \mathrm{~g}$ of methyl red $+0.02 \mathrm{~g}$ of bromothymol blue + $0.06 \mathrm{~g}$ of bromocresol green in $100 \mathrm{~mL}$ of $70 \%$ ethanol). After distilling $150 \mathrm{~mL}$ of the extract, distillation was considered completed. Blank solutions were prepared by using $50 \mathrm{~mL}$ of perchloric acid instead of the extract and distilled. Finally, the sample and blank distillates were titrated with $0.05 \mathrm{~N} \mathrm{HCL}$. The results were expressed as mg of TVB-N per $100 \mathrm{~g}$ of muscle according to:

$$
\text { TVB-N }\left(\frac{\mathrm{mg}}{100 \mathrm{~g} \text { sample }}\right)=\frac{\left(\mathrm{V}_{1}-\mathrm{V}_{0}\right) \times 14.01 \times \mathrm{N} \times 2 \times 100}{\mathrm{M}}
$$

where $\mathrm{V}_{1}$ and $\mathrm{V}_{0}$ are the titration volume of $\mathrm{HCl}(\mathrm{mL})$ for the sample extract and the blank solution, respectively; $\mathrm{N}$ is the normality of the $\mathrm{HCl}$ solution; and $\mathrm{M}$ is the weight of the sample (g). TVB-N measurements were performed in each sample in duplicate and then averaged.

\subsubsection{Drip loss after storage}

The drip loss after storage (DL) was evaluated by weighing the mackerel fillets, superficially dried with a soft paper, before and after storage. DL was expressed as the percent of mass loss according to Eq. (3):

$$
\operatorname{DL}(\%)=\frac{\left(M_{b s}-M_{a s}\right)}{M_{b s}} \times 100
$$

where $M_{b s}$ and $M_{a s}$ are the masses (g) of the fish fillets before and after storage, respectively.

\subsubsection{Water-holding capacity (WHC)}

For each determination, a portion of about $2 \mathrm{~cm} \times 4 \mathrm{~cm}$ was cut from the mackerel fillets, weighed, and centrifuged at $2200 \times \mathrm{g}$ and $4{ }^{\circ} \mathrm{C}$ for $10 \mathrm{~min}$ (Sorvall Evolution RC centrifuge, model 728311, Thermo Electron Corporation, Asheville, NC, USA). After centrifugation, the sample was superficially dried with a soft paper and weighed again. Water holding capacity was expressed as the percent of water retained per $100 \mathrm{~g}$ of water present in the sample prior to centrifuging according to: 


$$
\text { WHC }(\%)=\left(1-\frac{\left(M_{b c}-M_{a c}\right)}{M_{b c} \times m_{t w}}\right) \times 100
$$

where $M_{b c}$ and $M_{a c}$ are the masses (g) of the mackerel portions before and after centrifugation, respectively, and $\mathrm{m}_{\mathrm{tw}}$ is the mass fraction of total water present in the sample prior to centrifuging. $\mathrm{m}_{\mathrm{tw}}$ was evaluated by determining the mass loss in chopped fish flesh after oven drying at $105{ }^{\circ} \mathrm{C}$ until a constant weight was reached. In each sample, all WHC and $\mathrm{m}_{\mathrm{tw}}$ measurements were carried out in duplicate and then averaged.

\subsubsection{Color}

The flesh color of the Atlantic mackerel samples was characterized objectively according to the $L^{*}, a^{*}$, and $b^{*}$ color parameters in the CIELab uniform color space. To do so, a CM-3500d spectrophotometer managed with the color data software CM-S100w SpectraMagic ${ }^{\mathrm{TM}}$ (Konica Minolta, Tokyo, Japan) was employed. The illuminating and viewing configurations of the instrument complied with the $\mathrm{CIE}$ diffuse $/ 8^{\circ}$ geometry. The spectrophotometer operated in the reflectance specular included mode and the measuring aperture was $8 \mathrm{~mm}$ in diameter. Measurements were made with the D65 standard illuminant and a ten-degree observer angle. The instrument was calibrated with black and white standards before each series of analysis.

Six measurements at different locations were performed in each sample and the obtained $L^{*}$, $\mathrm{a}^{*}$, and $\mathrm{b}^{*}$ values were averaged. From these values, the total color change $\Delta \mathrm{E}^{*}$ was calculated according to Eq. (5):

$$
\Delta E^{*}=\sqrt{\left(L^{*}-L_{0}^{*}\right)^{2}+\left(a^{*}-a_{0}^{*}\right)^{2}+\left(b^{*}-b_{0}^{*}\right)^{2}}
$$

where $L_{0}^{*}, a_{0}^{*}$, and $b_{0}^{*}$ are the lightness, redness, and yellowness values of the control samples at day 0 .

\subsubsection{Firmness}

The firmness of the raw and cooked samples was evaluated by a compression test to determine the resistance of the muscle fibers. A Texture Analyzer (TA-XTPlus, Stable Micro System Ltd., Surrey, UK), equipped with a 36-mm diameter cylindrical probe $(\mathrm{P} / 36 \mathrm{R})$ and controlled by the Texture Exponent 32 software (v. 6.1.5.0), was employed. All the samples were tempered at room temperature for $30 \mathrm{~min}$ prior to the texture analysis. For the determinations, the mackerel fillets were compressed by $40 \%$ of their height $(1 \mathrm{~mm} / \mathrm{s}$ crosshead speed, $30 \mathrm{~kg}$ load cell) and the maximum force $(\mathrm{N})$ was recorded. In each fillet, firmness determinations were performed in duplicate and then averaged.

\subsubsection{Cooking loss}

Cooking loss $(\mathrm{CL})$ was determined by weighing the mackerel fillets, superficially dried with a soft paper, before and after cooking. CL was expressed as the percentage of mass loss according to Eq. (6):

$$
\mathrm{CL}(\%)=\frac{\left(\mathrm{M}_{\mathrm{bck}}-\mathrm{M}_{\mathrm{ack}}\right)}{\mathrm{M}_{\mathrm{bck}}} \times 100
$$

where $M_{b c k}$ and $M_{a c k}$ are the masses ( $g$ ) of the mackerel portions before and after cooking, respectively. In each sample, $\mathrm{CL}$ determinations were performed in triplicate and then averaged. 


\subsection{Statistical analysis}

Statistical analysis was performed using IBM SPSS Statistics v. 24.0.0.1 for Windows (IBM Corp., Armonk, NY, USA). After checking the prerequisites of normality and homogeneity of variances, a one-way analysis of variance (ANOVA) was performed. Significant differences among means were determined by a Tukey-b multiple range test in those cases in which the prerequisite of homogeneity of variances was fulfilled. Otherwise, a Tamhane's post hoc test was employed. The significance level was set at $5 \%$.

\section{RESULTS AND DISCUSSION}

\subsection{Microbial stability during storage}

Total viable bacteria in the control samples at day 0 were $4.0 \log _{10} \mathrm{cfu} / \mathrm{g}$ (Table 1$)$. This load is similar to that reported by Sofi, Raju, Lakshmisha, and Singh (2016) in Indian mackerel (Rastrelliger kanagurta) and Sanjuás-Rey, Gallardo, Barros-Velázquez, and Aubourg (2012) in Atlantic mackerel (Scomber scombrus). TVB counts in Iron Agar culture media reflect not only mesophile microorganisms, as conventional PCA counts do, but also psychrotrophic microbiota that can play a relevant role during cold storage and subsequent spoilage. The $\mathrm{H}_{2} \mathrm{~S}$-producing microorganisms, that is, black colonies considered as presumed Shewanella putrefaciens (M. E. López-Caballero, Martínez-Alvarez, Gómez-Guillén, \& Montero, 2007), recorded values of 3.2 $\log _{10} \mathrm{cfu} / \mathrm{g}$ in $\mathrm{C}$ samples, while aerobic mesophiles and Pseudomonas spp. were 4.8 and 3.9 $\log _{10} \mathrm{cfu} / \mathrm{g}$, respectively. Similarly, Reyes, Tabilo-Munizaga, Pérez-Won, Maluenda, and Roco (2015) reported counts of $3.3 \log _{10} \mathrm{cfu} / \mathrm{g}$ for S. putrefaciens in Chilean mackerel (Trachurus murphyi), while mesophiles and psychrophilic organisms were around $4.5 \log _{10} \mathrm{cfu} / \mathrm{g}$. In the present work, the counts of total viable and mesophilic microorganisms were similar and these data reveal the predominant mesophilic nature of the microbiota in the mackerel fillets at the early stages of conservation. Moreover, lactic bacteria and enterobacteria counts were close to $2 \log _{10} \mathrm{cfu} / \mathrm{g}$, while the luminescent bacteria, considered as presumed Photobacterium phosporeum (M. López-Caballero, Álvarez Torres, Sánchez-Fernández, \& Moral, 2002), remained below the limit of detection $\left(<2 \log _{10} \mathrm{cfu} / \mathrm{g}\right)$.

After 12 days of vacuum packaging at $5^{\circ} \mathrm{C}$, an increase in the total and mesophilic microflora of approximately $2 \log _{10}$ units was observed in the mackerel fillets stored at atmospheric pressure (Table 1). Under conditions of exclusion of oxygen, the growth of aerobic microorganisms is difficult and the development of microaerophilic and facultative species can be favored. Thus, the counts of presumptive $S$. putrefaciens increased by $3 \log _{10}$ units in AP_CS samples, while presumptive $P$. phosphoreum reached $4.1 \log _{10}$ ufc/g. During vacuum storage of fish, both $S$. putrefaciens and $P$. phosphoreum may grow and the predominant species will be the one that is found in the greatest amount before storage (Gram and Huss, 1996). According to Gram and Huss (1996), both microorganisms, among others, can use trimethylamine oxide as the final electron acceptor in anaerobic respiration and the subsequent trimethylamine production will be responsible for the unpleasant and off-odors, characteristic of fish spoilage. It is also important to point that, after 12 days of cold storage, AP_CS samples presented counts of enterobacteria exceeding $4 \log _{10} \mathrm{cfu} / \mathrm{g}$. Moreover, in one of the experiments, the presence of sulphite-reducing bacteria such as presumptive Clostridium perfringens, a highly ubiquitous anaerobic grampositive microorganism, was detected in 3 samples. In the other two replicated experiments $(n=$ 6 ), sulphite-reducing microorganisms remained under the detection limits.

By contrast, microbial counts in mackerel fillets stored at $50 \mathrm{MPa}$ for 12 days were similar or even lower than those of $C$ samples at day 0 . Thus, the results in Table 1 show a slight, but 
significant reduction $(p \leq 0.05)$ in total mesophiles, while the TVB counts remained constant. Hyperbaric storage was especially efficient in reducing presumptive S. putrefaciens and, thus, counts decreased below the detection limit after 12 days under pressure. The sensitivity of $S$. putrefaciens to pressure has been previously described in fish (Núñez-Flores, Castro, LópezCaballero, Montero, \& Gómez-Guillén, 2013; Ojagh, Núñez-Flores, López-Caballero, Montero, \& Gómez-Guillén, 2011), although at pressure levels considerably higher than that used in this paper. In this study, lactic acid bacteria counts remained constant, while those of enterobacteria reduced by more than $2 \log _{10}$ units. This confirms the greater sensitivity of gram-negative bacteria to pressure compared with gram-positive bacteria, even at moderate pressure levels (Shigehisa, Ohmori, Saito, Taji, \& Hayashi, 1991).

Data in Table 1 clearly prove that hyperbaric cold storage is much more effective than conventional refrigeration for extending the shelf-life of mackerel fillets from a microbiological point of view. Our results agree with previous data that show that, unlike conventional refrigeration, hyperbaric storage of hake loins at $50 \mathrm{MPa}$ and $5{ }^{\circ} \mathrm{C}$ allowed to maintain microbial counts (total mesophiles and enterobacteria) unaltered for, at least, 7 days (Otero et al., 2017). By contrast, Fidalgo et al. (2018) observed that hyperbaric storage at $50 \mathrm{MPa}$ and room temperature could not avoid microbial proliferation in Atlantic salmon. Thus, after 10 days, total aerobic mesophiles and anaerobic bacteria counts increased by about 3 and $4 \log _{10}$ units, respectively and pressure levels of, at least, $75 \mathrm{MPa}$ were needed to inhibit microbial growth. These results reveal the relevant role that temperature plays for microbial growth during hyperbaric storage as also occurs during conventional fish preservation at atmospheric pressure.

\subsection{Lipid stability during storage}

Table 2 shows the amount of total polymerization and hydrolytic compounds in the lipids extracted from C, AP_CS, and HP_CS samples. After 12 days of storage, the amount of polymerization compounds remained unaltered in all the samples, whichever the storage method employed. By contrast, hydrolytic compounds significantly increased $(p<0.05)$ when the mackerel fillets were stored at atmospheric pressure.

The quantitative determination of polymerization compounds through high-performance sizeexclusion chromatography is an excellent tool to evaluate oxidation in oils rich in polyunsaturated fatty acids such as fish oils (Giménez, Gómez-Guillén, Pérez-Mateos, Montero, \& Márquez-Ruiz, 2011; Heinzelmann, Franke, Velasco, \& Márquez-Ruiz, 2000). The high susceptibility to oxidation of PUFA, even at low temperatures, and the great instability of the primary oxidation compounds (hydroperoxides) favor the rapid appearance of secondary oxidation compounds in relevant amounts. In fish lipids, the major secondary oxidation compounds are polymerization compounds formed by condensation reactions (Márquez-Ruiz, Holgado, \& Velasco, 2013).

The results shown in Table 2 clearly reveal that hyperbaric cold storage, at $50 \mathrm{MPa}$ and $5{ }^{\circ} \mathrm{C}$, did not enhance lipid oxidation in mackerel fillets. By contrast, Fidalgo et al. (2018) reported that hyperbaric storage (50-75 MPa) at $25^{\circ} \mathrm{C}$ increased peroxide and TBARS values in salmon fillets compared to conventional refrigeration $\left(0.1 \mathrm{MPa} / 4{ }^{\circ} \mathrm{C}\right)$. These findings suggest that storage temperature could play a relevant role in lipid oxidation under pressure as it is well known to occur at atmospheric conditions (Márquez-Ruiz et al., 2013).

The results obtained in this paper are consistent with data in the literature that indicate that short periods ( $\leq 30 \mathrm{~min}$ ) at pressures lower than $200 \mathrm{MPa}$ do not affect lipid stability in Atlantic mackerel muscle, although treatments above 200-300 MPa can considerably enhance lipid oxidation (Ohshima et al., 1992; Senturk \& Alpas, 2013). Thus, Ohshima et al. (1992) observed that peroxide values increased by more than twice in mackerel fillets processed at $400-600 \mathrm{MPa}$ 
for $30 \mathrm{~min}$, but no increase was detected in the samples pressurized at $200 \mathrm{MPa}$. Accordingly, Senturk and Alpas (2013) found that thiobarbituric acid values in mackerel fillets increased only slightly after pressure processing at 200-300 MPa for 5-15 min, but they increased considerably when the samples were treated at $400 \mathrm{MPa}$. Our results reveal that pressurization at $50 \mathrm{MPa}$, even for long periods, did not enhance lipid oxidation probably because pressures lower than 100-150 MPa do not have a significant destabilizing effect on cell membranes and proteins, the target sites implied in triggering pressure-induced lipid oxidation in fish muscle (Medina-Meza et al., 2014; Truong et al., 2015).

Unlike conventional refrigeration, hyperbaric cold storage $\left(50 \mathrm{MPa} / 5^{\circ} \mathrm{C}\right)$ was also efficient in inhibiting lipid hydrolysis in mackerel fillets (Table 2). Figure 1 depicts three representative HPSEC chromatograms of C, AP_CS, and HP_CS samples to illustrate the differences found in the peaks corresponding to hydrolytic compounds (peak 3: diacylglycerols and peak 4: monoacylglycerols plus free fatty acids). Figure 1 certainly shows that, after 12 days of storage, peaks 3 and 4 did not significantly differ in C and HP_CS samples, but they were significantly higher in AP_CS samples. The formation of free fatty acids by hydrolysis does not itself lead to nutritional losses, although it has been associated with lipid oxidation enhancement and fish muscle texture changes (Sikorski \& Kolakowska, 1994; Yoshida, Kondo, \& Kajimoto, 1992). Clearly, in the present work, no influence of the hydrolytic level on the formation of polymerization compounds was observed.

Lipid hydrolysis in fish during cold storage has been attributed to both endogenous and microbial enzymatic activity (Huss, 1995; Whittle, Hardy, \& Hoobs, 1990). Before the end of the microbial lag phase, fatty acid release is mostly due to endogenous enzyme activity (lipases and phospholipases) but, after the escalation of bacterial growth, microbial activity becomes the major contributor to hydrolytic degradation. The data shown in Table 2 and Figure 1 are consistent with the microbial results described in Section 3.1. Thus, the largest microbial counts in AP_CS samples may account for the largest hydrolysis extent detected in these samples.

Moreover, the results in Table 2 not only demonstrate that hyperbaric cold storage inhibited microbial lipid hydrolysis, but they also confirm that pressure did not enhance autolytic lipid degradation. In this sense, many data in the literature show that lipid hydrolysis in fish muscles is not accentuated under pressure (D. Chevalier, Le Bail, \& Ghoul, 2001; Ohshima et al., 1992; Ortea et al., 2010). For example, D. Chevalier et al. (2001) did not find significant changes in the FFA content in turbot fillets treated at 100-200 MPa for 15-30 min, while Ohshima et al. (1992) reported no increased FFA contents in cod and mackerel muscles pressurized, even at $600 \mathrm{MPa}$, for $30 \mathrm{~min}$.

Table 3 summarizes the fatty acid composition of the lipids extracted from C, AP_CS, and HP_CS mackerel fillets. It lists groups of saturated, monounsaturated, and polyunsaturated fatty acids and also the sum of omega-3 polyunsaturated fatty acids, i.e., EPA (eicosapentanoic acid, 20:5) and DHA (docosahexanoic acid, 22:6). The results presented in Table 3 for $C$ samples are consistent with data recently reported for Atlantic mackerel from different seasons and geographical origin (Romotowska, Karlsdóttir, Gudjónsdóttir, Kristinsson, \& Arason, 2016). Moreover, comparisons among the samples reveal that no significant changes occurred on the fatty acid composition during storage, whichever the conditions employed.

Also, Table 3 includes the polyene index calculated as an indirect measurement of oxidative stability and often reported in studies on fish oils as a measurement of the loss of omega- 3 polyunsaturated fatty acids (Eymard, Baron, \& Jacobsen, 2009; Giménez et al., 2011; Romotowska et al., 2016). No significant changes were found in the polyene index in consistency with values obtained for polymerization compounds (Table 2). Therefore, these results confirm that cold storage for 12 days, neither at atmospheric pressure or at $50 \mathrm{MPa}$, led to significant oxidation in mackerel fillets.

\subsection{Protein stability during storage}

Innovative Food Science and Emerging Technologies 51 (2019) 41-50 
Protein stability during cold storage of the mackerel fillets, either at atmospheric pressure or at $50 \mathrm{MPa}$, was assessed by analyzing the solubility and the electrophoretic profiles of the sarcoplasmic and myofibrillar fractions before and after storage.

The solubility of the sarcoplasmic proteins in the control samples at day 0 was $2.37 \pm 0.18 \mathrm{~g} / 100$ $\mathrm{g}$ (Table 4). After 12 days at $5{ }^{\circ} \mathrm{C}$, the solubility remained unaltered in the mackerel fillets stored at atmospheric pressure, but it reduced by $66 \%$ when the samples were kept at $50 \mathrm{MPa}$. Previous results in the literature prove that cold storage at atmospheric pressure for some days or weeks hardly affects the extractability of water-soluble proteins in fish (Alinasabhematabadi, 2015; Kaale \& Eikevik, 2016), but pressure processing reduces it significantly (Ohshima et al., 1992; Ortea et al., 2010; M. Pazos et al., 2015; Manuel Pazos, Méndez, Gallardo, \& Aubourg, 2014; Teixeira et al., 2013). In general, the higher the pressure, the lower the solubility of the sarcoplasmic proteins, but differences seem to exist among fish species. In mackerel muscle, Manuel Pazos et al. (2014) observed that the solubility of sarcoplasmic proteins reduced significantly after pressure processing at $300-450 \mathrm{MPa}$ for $5 \mathrm{~min}$, but not at $150 \mathrm{MPa}$. In our study, pressure applied during storage was relatively low, but the long time under pressure could be responsible for the low extractability of sarcoplasmic proteins. In this sense, Teixeira et al. (2013) reported a significant effect of the pressure holding time on the solubility of watersoluble proteins in sea bass fillets stored at $100 \mathrm{MPa}$ for 0-30 min.

SDS-PAGE gel profiles confirmed that, unlike conventional cold storage, hyperbaric storage at $50 \mathrm{MPa}$ produced a noticeable impact on the sarcoplasmic proteins, mainly in the bands with molecular weights close to 100 and $50 \mathrm{kDa}$ that disappeared almost completely. Moreover, the intensity of some low molecular weight (LMW) bands increased visibly in HP_CS samples. All these results suggest that hyperbaric storage for 12 days degraded certain sarcoplasmic proteins that remained unaltered when cold storage was carried out at atmospheric pressure.

Reductions in the intensity of bands close to 100 and $50 \mathrm{kDa}$ after pressure processing have been previously reported in several fish species (Dominique Chevalier, Sequeira-Munoz, Le Bail, Simpson, \& Ghoul, 2000; Ohshima et al., 1992; Manuel Pazos et al., 2014; Tironi, Le Bail, \& de Lamballerie, 2007). In pressurized mackerel (300-450 MPa, $5 \mathrm{~min}$ ), Manuel Pazos et al. (2014) identified these bands by MS/MS sequencing and database homology and assigned the band close to $100 \mathrm{kDa}$ to unnamed protein products (UNP) similar to glycogen phosphorylase muscle form-like, while the band close to $50 \mathrm{kDa}$ was assigned to UNP similar to $\beta$-enolase-like isoform 1. Moreover, other authors have noted the presence of new LMW bands in pressure processed fish (Dominique Chevalier et al., 2000; Ohshima et al., 1992; Tironi et al., 2007). In this sense, Dominique Chevalier et al. (2000) speculated that these new bands corresponded to fragments of sarcoplasmic proteins degraded by pressurization or new water-soluble fragments derived from myofibrillar proteins.

The solubility of myofibrillar proteins of fresh mackerel at day 0 was $7.47 \pm 0.23 \mathrm{~g} / 100 \mathrm{~g}$ (Table 4). After 12 days of storage at $5{ }^{\circ} \mathrm{C}$, the solubility significantly reduced $(p<0.05)$ by more than $50 \%$ in both AP_CS and HP_CS samples. Our results confirm previous data that show that chilled and frozen storage decreases the solubility of myofibrillar proteins in mackerel muscle (Alinasabhematabadi, 2015; Manuel Pazos et al., 2014). Reductions in salt-soluble protein solubility have been also described in pressure processed fish and sea products (Dominique Chevalier et al., 2000; Ojagh et al., 2011). As occurred in sarcoplasmic proteins, the higher the pressure and the longer the holding time, the lower the solubility of the myofibrillar proteins, but differences also exist among fish species.

The electrophoretic patterns obtained in the SDS-PAGE gels showed significant differences among C, AP_CS, and HP_CS samples (Figure 2). Control mackerel fillets presented six main bands: one close to $200 \mathrm{kDa}$ and the other five between 50 and $25 \mathrm{kDa}$. Cold storage for 12 days at atmospheric pressure significantly reduced the intensity of the $\sim 25-\mathrm{kDa}$ band that almost disappeared. After hyperbaric cold storage, changes were, to some extent, different. Thus, the intensity of the $\sim 200-\mathrm{kDa}$ band, tentatively assigned to myosin heavy chain (MHC), reduced, while the intensity of a $>250-\mathrm{kDa}$ band increased substantially. Moreover, bands between 50 and $30 \mathrm{kDa}$ became more intense and, as occurred in AP_CS samples, the $\sim 25$ - 
kDa band disappeared. These differences between AP_CS and HP_CS samples could be due to a direct effect of pressure on myofibrillar proteins but also to a pressure-induced effect on the autolytic capacity of endogenous proteases.

Our results confirm previous findings that prove that myosin is a pressure-labile protein. Thus, Chéret, Hernández-Andrés, Delbarre-Ladrat, de Lamballerie, and Verrez-Bagnis (2005) and Ojagh et al. (2011) also described less intense MHC bands in sea bass and Atlantic salmon after pressure treatment at $300 \mathrm{MPa}$ for 5 and $10 \mathrm{~min}$, respectively, and they suggested that this may be due to protein aggregation. In this sense, Ramirez-Suarez and Morrissey (2006) reported that pressure processing at $275 \mathrm{MPa}$ for 2-6 min reduced the intensity of the MHC band and promoted the formation of heavy molecular weight polypeptides (> $200 \mathrm{kDa}$ ) in albacore tuna, probably through disulfide bonding. DSC studies in cod treated at $100 \mathrm{MPa}$ for 20 min also confirmed that pressure induces myosin denaturation (Angsupanich \& Ledward, 1998), but $300 \mathrm{MPa}$ were needed to alter actin structure. Accordingly, in this paper, we did not observe any change in the $\sim 42-\mathrm{kDa}$ band, tentatively assigned to actin.

All these results clearly show that hyperbaric storage at $50 \mathrm{MPa}$ for 12 days induced significant changes in both sarcoplasmic and myofibrillar proteins of mackerel muscle. The significant reductions detected in the solubility data could be attributed to pressure-induced protein denaturation and the formation of insoluble protein aggregates. On the other hand, the reductions observed in the intensity of some bands in the SDS-PAGE gels could be related to this aggregation process, but also to protein degradation producing smaller protein residues and the appearance of new protein bands and/or the thickening of others.

\subsection{Effects of storage on fish-quality indicators}

Cold storage for 12 days, either at atmospheric pressure or at $50 \mathrm{MPa}$, produced significant changes in most of the quality indicators of the mackerel samples (Table 5). Thus, increased $\mathrm{pH}, \mathrm{TVB}-\mathrm{N}, \mathrm{L}^{*}$, and $\mathrm{b}^{*}$ values, considerable drip losses, and reduced water-holding capacity were observed in both AP_CS and HP_CS samples compared with $\mathrm{C}$ fillets. All these changes have been frequently described in the literature during cold storage of fish and fish products (Ashie et al., 1996; Huss, 1995), but it is important to note that most of these alterations were significantly slighter in the samples stored under pressure.

After 12 days of storage at $5{ }^{\circ} \mathrm{C}$, mean $\mathrm{pH}$ increased by 0.34 units in the samples stored at atmospheric pressure, while the total volatile basic-nitrogen content exceeded by far the usually recommended limit of acceptance (30-40 mg/100 g) for human consumption (Connell, 1990; Goulas \& Kontominas, 2005). By contrast, mean pH and TVB-N values in HP_CS samples, even though significantly larger than those in $C$ fillets, were similar to those usually reported in the literature for fresh mackerel that range between 5.7 and 6.3 (Bennour, El Marrakchp, Bouchritf, Hamama, \& El Ouadaa, 1991; Karoui \& Hassoun, 2017; Pinter, Maltar-Strmečki, Kozačinski, Njari, \& Cvrtila Fleck, 2015) and between 10 and 20 mg/100 g (Bennour et al., 1991; Dogruyol \& Mol, 2017; Goulas \& Kontominas, 2005), respectively. pH and TVB-N increases in seafood during cold storage are mainly due to the basic compounds produced when the fish muscle is degraded by enzymatic reactions and microbial activity (Huss, 1995). Therefore, our results are consistent with the microbial counts described in Section 3.1 and confirm previous findings observed for hake loins stored at $50 \mathrm{MPa}$ and $5{ }^{\circ} \mathrm{C}$ for 7 days (Otero et al., 2017) that proved that hyperbaric storage not only inhibits microbial growth but it does not enhance other autolytic processes that produce volatile bases.

Hyperbaric storage was also efficient in reducing drip losses and retaining the water-holding capacity to a larger extent than conventional cold storage (Table 5). As described in Section 3.3, myofibrillar proteins, the main responsible for the water-binding properties, suffered important denaturation during cold storage and, consequently, significant drip losses and reduced water-holding capacity were detected in both AP_CS and HP_CS samples. However, the electrophoretic data showed clear differences between the salt-soluble protein profile of 
AP_CS and HP_CS samples that could be responsible for the significant differences observed in the DL and WHC data.

Pressure, at the level applied, did not affect the hardness and color evolution during cold storage. After 12 days at $5{ }^{\circ} \mathrm{C}$, hardness remained unaltered in both AP_CS and HP_CS mackerel fillets and the appearance of both samples was good, even though significant color changes were detected. Thus, $L^{*}$ and $b^{*}$ values increased by more than $10 \%$ and $40 \%$, respectively, and $\Delta \mathrm{E}$ values were larger than 6 at the end of storage. Color differences larger than 2-4 are considered as perceptible by the naked eye and, therefore, AP_CS and HP_CS mackerel fillets would be perceived as lighter and more yellowish than $C$ samples by consumers, even though color differences close to 6 are small in practical terms.

It is well-known that pressure processing can affect the texture and color of fish flesh and make fish to acquire a harder texture and a cooked, opaque appearance (Matser et al., 2000; Truong et al., 2015). In general, the larger the pressure and the longer the pressure holding time, the more apparent these changes, but the pressure level at which a marked effect is produced depends on the fish species and the treatment conditions (Truong et al., 2015). In this paper, HP_CS fillets did not present an increased hardness or a cooked aspect, but a raw appearance, probably because the pressure level applied during storage was low enough to not affect the mechanisms implied in pressure-induced texture and color alterations. In this sense, after comparing texture profiles and thermograms of pressure-treated cod samples, Angsupanich and Ledward (1998) suggested that the loss of myosin structure under pressure leads to a decrease in adhesiveness, gumminess, and cohesiveness, while the unfolding of actin is responsible for increases in gumminess, hardness, and adhesiveness. Electrophoretic profiles of mackerel fillets after cold storage did not show actin denaturation in either AP_CS or HP_CS samples and, therefore, no hardness changes should be expected.

The quality of the mackerel fillets was also evaluated after cooking. Heating induced additional denaturation and aggregation of proteins and this produced significant weight losses, texture and color changes in C, AP_CS, and HP_CS samples. Thus, cooking losses, accounting for the release of water, soluble proteins, and fats from the tissue, were close to $15 \%$ in all the samples. Moreover, all the mackerel fillets became softer and acquire an opaque appearance. After cooking, texture differences appeared and AP_CS samples were significantly harder than the rest. By contrast, no color differences existed between AP_CS and HP_CS samples, although differences between control and cold stored fillets still persisted. Nevertheless, these differences were less evident than in raw samples and, probably, they would not be perceived by consumers $(\Delta \mathrm{E}<4)$.

\section{CONCLUSIONS}

Hyperbaric cold storage, at $50 \mathrm{MPa}$ and $5{ }^{\circ} \mathrm{C}$, resulted a very effective technology to extend the shelf-life of Atlantic mackerel fillets. Thus, pressure not only avoided microbial growth in the samples for, at least, 12 days but it also reduced $\mathrm{H}_{2}$-S producing microorganisms and enterobacteria below the detection limits. Thus, the microbial quality of the samples kept at 50 $\mathrm{MPa}$ for 12 days was better than that of control fillets at day 0 . The inhibition of microbial metabolism under pressure resulted in no lipid hydrolysis and lower $\mathrm{pH}$ and TVB-N values in HP_CS samples compared with AP_CS samples. Moreover, drip losses, water-holding capacity, and hardness after cooking were significantly less affected, even though significant changes in the protein profile were observed after hyperbaric storage.

Our results show that hyperbaric cold storage could be an interesting technology for the preservation of fatty fish. Thus, at the conditions tested in this study, no lipid degradation was observed in Atlantic mackerel. However, more studies are needed to confirm the potential benefits of this novel technology for the seafood industry. Thus, future research works on lipid degradation under pressure should include several fatty-fish species, longer storage times, and different pressure and temperature conditions to evaluate the effect that these factors can have during hyperbaric storage. 


\section{Acknowledgments}

This work was supported by the State Plan for Scientific and Technical Research and Innovation 2013-2016 of the Spanish Ministry of Economy and Competitiveness (MINECO) through the CONSOLIDER-Network MAT2015-71070-REDC and the project AGL2014-52825. The authors thank Ignacio Rodríguez and Ignacio Escudero, both technicians at ICTAN-CSIC, for their assistance in the lab work. The authors also thank Nerea Jáuregui, Master student, for her help in obtaining and processing part of the data.

\section{REFERENCES}

Alinasabhematabadi, L. (2015). Protein oxidation in Atlantic mackerel (Scomber scombrus) during chilled and frozen storage. Norwegian University of Science and Technology, Trondheim.

Angsupanich, K., \& Ledward, D. A. (1998). High pressure treatment effects on cod (Gadus morhua) muscle. Food Chemistry, 63(1), 39-50.

Ashie, I. N., Smith, J. P., \& Simpson, B. K. (1996). Spoilage and shelf-life extension of fresh fish and shellfish. Critical Reviews in Food Science and Nutrition, 36(1-2), 87-121.

Bennour, M., El Marrakchp, A., Bouchritf, N., Hamama, A., \& El Ouadaa, M. (1991). Chemical and microbiological assessments of mackerel (Scomber scombrus) stored in ice. J Food Prot, 54(10), 784-792.

Bermejo-Prada, A., Colmant, A., Otero, L., \& Guignon, B. (2017). Industrial viability of the hyperbaric method to store perishable foods at room temperature. Journal of Food Engineering, 193, 76-85.

Bermejo-Prada, A., López-Caballero, M. E., \& Otero, L. (2016). Hyperbaric storage at room temperature: Effect of pressure level and storage time on the natural microbiota of strawberry juice. Innovative Food Science \& Emerging Technologies, 33, 154-161.

Bligh, E. G., \& Dyer, W. J. (1959). A rapid method of total lipid extraction and purification. Can J Biochem Physiol, 37(8), 911-917.

Bradford, M. M. (1976). A rapid and sensitive method for the quantitation of microgram quantities of protein utilizing the principle of protein-dye binding. Analytical Biochemistry, 72(1), 248-254.

Community, E. (2005). EC Commission Regulation No 2074/2005 of 5 December 2005. . Official Journal of the European Union L, 338, 27-59.

Connell, J. J. (1990). Methods of assessing and selecting for quality. In Control of fish quality (3rd ed. ed., pp. 122-150). Oxford: Fishing News Books.

Charm, S. E., Longmaid, H. E., \& Carver, J. (1977). Simple system for extending refrigerated, nonfrozen preservation of biological-material using pressure. Cryobiology, 14(5), 625636.

Chéret, R., Hernández-Andrés, A., Delbarre-Ladrat, C., de Lamballerie, M., \& Verrez-Bagnis, V. (2005). Proteins and proteolytic activity changes during refrigerated storage in sea bass (Dicentrarchus labrax L.) muscle after high-pressure treatment. European Food Research and Technology, 222(5), 527.

Chevalier, D., Le Bail, A., \& Ghoul, M. (2001). Effects of high pressure treatment (100-200 MPa) at low temperature on turbot (Scophthalmus maximus) muscle. Food Research International, 34(5), 425-429.

Chevalier, D., Sequeira-Munoz, A., Le Bail, A., Simpson, B. K., \& Ghoul, M. (2000). Effect of pressure shift freezing, air-blast freezing and storage on some biochemical and 
physical properties of turbot (Scophthalmus maximus). LWT - Food Science and Technology, 33(8), 570-577.

Dogruyol, H., \& Mol, S. (2017). Effect of Irradiation on Shelflife and Microbial Quality of ColdStored Sous-Vide Mackerel Fillets. Journal of Food Processing and Preservation, 41(2).

Duarte, R. V., Moreira, S. A., Fernandes, P. A. R., Santos, D. I., Inácio, R. S., Alves, S. P., Bessa, R. J. B., \& Saraiva, J. A. (2017). Whey cheese longer shelf-life achievement at variable uncontrolled room temperature and comparison to refrigeration. Journal of Food Processing and Preservation, e13307-n/a.

Eymard, S., Baron, C. P., \& Jacobsen, C. (2009). Oxidation of lipid and protein in horse mackerel (Trachurus trachurus) mince and washed minces during processing and storage. Food Chemistry, 114(1), 57-65.

Fattouch, S., Sadok, S., Raboudi-Fattouch, F., \& Slama, M. B. (2008). Damage inhibition during refrigerated storage of mackerel (Scomber scombrus) fillets by a presoaking in quince (Cydonia oblonga) polyphenolic extract. International Journal of Food Science and Technology, 43(11), 2056-2064.

Fidalgo, L. G., Lemos, Á. T., Delgadillo, I., \& Saraiva, J. A. (2018). Microbial and physicochemical evolution during hyperbaric storage at room temperature of fresh Atlantic salmon (Salmo salar). Innovative Food Science \& Emerging Technologies, 45(Supplement C), 264-272.

Giménez, B., Gómez-Guillén, M. C., Pérez-Mateos, M., Montero, P., \& Márquez-Ruiz, G. (2011). Evaluation of lipid oxidation in horse mackerel patties covered with borage-containing film during frozen storage. Food Chemistry, 124(4), 1393-1403.

Goulas, A. E., \& Kontominas, M. G. (2005). Effect of salting and smoking-method on the keeping quality of chub mackerel (Scomber japonicus): biochemical and sensory attributes. Food Chemistry, 93(3), 511-520.

Gram, L., \& Huss, H. H. (1996). Microbiological spoilage of fish and fish products. International Journal of Food Microbiology, 33(1), 121-137.

Heinzelmann, K., Franke, K., Velasco, J., \& Márquez-Ruiz, G. (2000). Microencapsulation of fish oil by freeze-drying techniques and influence of process parameters on oxidative stability during storage. European Food Research and Technology, 211(4), 234-239.

Huss, H. H. (1995). Quality and quality changes in fresh fish. In. Rome: Food and Agriculture Organization of the United Nations

IUPAC. (1992a). Standard Method 2.507: Determination of Polar Compounds in Frying Fats, in Standard Methods for the Analysis of Oils, Fats and Derivatives. In ( $7^{\text {th }}$ ed.). Blackwell, Oxford, England: International Union of Pure and Applied Chemistry.

IUPAC. (1992b). Standard Method 2.508: Determination of Polymerized Triglycerides in Oils and Fats by High Performance Liquid Chromatography. In ( $7^{\text {th }}$ ed.). Blackwell, Oxford, England: International Union of Pure and Applied Chemistry.

Kaale, L. D., \& Eikevik, T. M. (2016). Changes of proteins during superchilled storage of Atlantic salmon muscle (Salmo salar). Journal of Food Science and Technology, 53(1), 441-450.

Karoui, R., \& Hassoun, A. (2017). Efficiency of rosemary and basil essential oils on the shelf-life extension of Atlantic mackerel (Scomber scombrus) fillets stored at $2{ }^{\circ} \mathrm{C}$. Journal of AOAC International, 100(2), 335-344.

López-Caballero, M., Álvarez Torres, M., Sánchez-Fernández, J., \& Moral, A. (2002). Photobacterium phosphoreum isolated as a luminescent colony from spoiled fish, cultured in model system under controlled atmospheres. European Food Research and Technology, 215(5), 390-395.

López-Caballero, M. E., Martínez-Alvarez, O., Gómez-Guillén, M. d. C., \& Montero, P. (2007). Quality of thawed deepwater pink shrimp (Parapenaeus longirostris) treated with melanosis-inhibiting formulations during chilled storage. International Journal of Food Science \& Technology, 42(9), 1029-1038. 
Márquez-Ruiz, G., Holgado, F., \& Velasco, J. (2013). Mechanisms of oxidation in food lipids. In G. Bartosz (Ed.), Food oxidants and antioxidants: Chemical, biological, and functional properties (pp. 80-113). Boca Raton, FL: CRC Press.

Matser, A. M., Stegeman, D., Kals, J., \& Bartels, P. V. (2000). Effects of high pressure on colour and texture of fish. High Pressure Research, 19(1-6), 109-115.

Medina-Meza, I. G., Barnaba, C., \& Barbosa-Cánovas, G. V. (2014). Effects of high pressure processing on lipid oxidation: A review. Innovative Food Science \& Emerging Technologies, 22, 1-10.

Núñez-Flores, R., Castro, A. X., López-Caballero, M. E., Montero, P., \& Gómez-Guillén, M. C. (2013). Functional stability of gelatin-lignosulphonate films and their feasibility to preserve sardine fillets during chilled storage in combination with high pressure treatment. Innovative Food Science \& Emerging Technologies, 19(Supplement C), 95103.

Ohshima, T., Nakagawa, T., \& Koizumi, C. (1992). Effect of high hydrostatic pressure on the enzymatic degradation of phospholipids in fish muscle during storage. In E. G. Bligh (Ed.), Seafood Science and Technology (pp. 64-75). Oxford, UK: Fishing News Books.

Ojagh, S. M., Núñez-Flores, R., López-Caballero, M. E., Montero, M. P., \& Gómez-Guillén, M. C. (2011). Lessening of high-pressure-induced changes in Atlantic salmon muscle by the combined use of a fish gelatin-lignin film. Food Chemistry, 125(2), 595-606.

Ortea, I., Rodríguez, A., Tabilo-Munizaga, G., Pérez-Won, M., \& Aubourg, S. P. (2010). Effect of hydrostatic high-pressure treatment on proteins, lipids and nucleotides in chilled farmed salmon (Oncorhynchus kisutch) muscle. European Food Research and Technology, 230(6), 925-934.

Otero, L., Pérez-Mateos, M., \& López-Caballero, M. E. (2017). Hyperbaric cold storage versus conventional refrigeration for extending the shelf-life of hake loins. Innovative Food Science \& Emerging Technologies, 41, 19-25.

Pazos, M., Méndez, L., Fidalgo, L., Vázquez, M., Antonio Torres, J., Aubourg, S. P., \& Saraiva, J. A. (2015). Effect of high-pressure processing of Atlantic mackerel (Scomber scombrus) on biochemical changes during commercial frozen storage. Food and Bioprocess Technology, 8(10), 2159-2170.

Pazos, M., Méndez, L., Gallardo, J. M., \& Aubourg, S. P. (2014). Selective-Targeted Effect of High-Pressure Processing on Proteins Related to Quality: a Proteomics Evidence in Atlantic Mackerel (Scomber scombrus). Food and Bioprocess Technology, 7(8), 23422353.

Pinter, N., Maltar-Strmečki, N., Kozačinski, L., Njari, B., \& Cvrtila Fleck, Ž. (2015). Impact of radiation treatment on chemical, biochemical and sensory properties, and microbiological quality of mackerel. Radiation Physics and Chemistry, 117, 23-25.

Ramirez-Suarez, J. C., \& Morrissey, M. T. (2006). Effect of high pressure processing (HPP) on shelf life of albacore tuna (Thunnus alalunga) minced muscle. Innovative Food Science \& Emerging Technologies, 7(1), 19-27.

Reyes, J. E., Tabilo-Munizaga, G., Pérez-Won, M., Maluenda, D., \& Roco, T. (2015). Effect of high hydrostatic pressure (HHP) treatments on microbiological shelf-life of chilled Chilean jack mackerel (Trachurus murphyi). Innovative Food Science \& Emerging Technologies, 29(Supplement C), 107-112.

Rode, T. M., \& Hovda, M. B. (2016). High pressure processing extend the shelf life of fresh salmon, cod and mackerel. Food Control, 70, 242-248.

Romotowska, P. E., Karlsdóttir, M. G., Gudjónsdóttir, M., Kristinsson, H. G., \& Arason, S. (2016). Seasonal and geographical variation in chemical composition and lipid stability of Atlantic mackerel (Scomber scombrus) caught in Icelandic waters. Journal of Food Composition and Analysis, 49(Supplement C), 9-18. 
Sanjuás-Rey, M., Gallardo, J. M., Barros-Velázquez, J., \& Aubourg, S. P. (2012). Microbial activity inhibition in chilled mackerel (Scomber scombrus) by employment of an organic acid-icing system. Journal of Food Science, 77(5), M264-M269.

Senturk, T., \& Alpas, H. (2013). Effect of high hydrostatic pressure treatment (HHPT) on quality and shelf life of Atlantic mackerel (Scomber scombrus). Food and Bioprocess Technology, 6(9), 2306-2318.

Sequeira-Munoz, A., Chevalier, D., LeBail, A., Ramaswamy, H. S., \& Simpson, B. K. (2006). Physicochemical changes induced in carp (Cyprinus carpio) fillets by high pressure processing at low temperature. Innovative Food Science \& Emerging Technologies, $7(1-2), 13-18$.

Shigehisa, T., Ohmori, T., Saito, A., Taji, S., \& Hayashi, R. (1991). Effects of high hydrostatic pressure on characteristics of pork slurries and inactivation of microorganisms associated with meat and meat products. Int J Food Microbiol, 12(2-3), 207-215.

Sikorski, Z. E., \& Kolakowska, A. (1994). Changes in proteins in frozen stored fish. In Z. E. Sikorski, B. S. Pan \& F. Shahidi (Eds.), Seafood proteins (pp. 99-112). New York: Chapman \& Hall.

Sofi, F. R., Raju, C. V., Lakshmisha, I. P., \& Singh, R. R. (2016). Antioxidant and antimicrobial properties of grape and papaya seed extracts and their application on the preservation of Indian mackerel (Rastrelliger kanagurta) during ice storage. Journal of Food Science and Technology, 53(1), 104-117.

Teixeira, B., Fidalgo, L., Mendes, R., Costa, G., Cordeiro, C., Marques, A., Saraiva, J. A., \& Nunes, M. L. (2013). Changes of enzymes activity and protein profiles caused by high-pressure processing in sea bass (Dicentrarchus labrax) fillets. J Agric Food Chem, 61(11), 28512860.

Tironi, V., Le Bail, A., \& de Lamballerie, M. (2007). Effects of pressure-shift freezing and pressure-sssisted thawing on sea bass (Dicentrarchus labrax) quality. Journal of Food Science, 72(7), C381-C387.

Torres, J. A., Vázquez, M., Saraiva, J. A., Gallardo, J. M., \& Aubourg, S. P. (2013). Lipid damage inhibition by previous high pressure processing in white muscle of frozen horse mackerel. European Journal of Lipid Science and Technology, 115(12), 1454-1461.

Truong, B. Q., Buckow, R., Stathopoulos, C. E., \& Nguyen, M. H. (2015). Advances in highpressure processing of fish muscles. Food Engineering Reviews, 7(2), 109-129.

Vázquez, M., Torres, J. A., Gallardo, J. M., Saraiva, J., \& Aubourg, S. P. (2013). Lipid hydrolysis and oxidation development in frozen mackerel (Scomber scombrus): Effect of a high hydrostatic pressure pre-treatment. Innovative Food Science and Emerging Technologies, 18, 24-30.

Whittle, K., Hardy, R., \& Hoobs, G. (1990). Chilled fish and fishery products. In T. Gormeley (Ed.), Chilled foods. The state of the art (pp. 87-116). New York, NY: Elservier Applied Science.

Yagiz, Y., Kristinsson, H. G., Balaban, M. O., \& Marshall, M. R. (2007). Effect of high pressure treatment on the quality of rainbow trout (Oncorhynchus mykiss) and mahi mahi (Coryphaena hippurus). Journal of Food Science, 72(9), C509-515.

Yoshida, H., Kondo, I., \& Kajimoto, G. (1992). Participation of free fatty acids in the oxidation of purified soybean oil during microwave heating. Journal of the American Oil Chemists' Society, 69(11), 1136-1140. 
TABLE 1 Microbial counts in Atlantic mackerel fillets before (C samples, $n=9)$ and after 12 days of cold storage $\left(5^{\circ} \mathrm{C}\right.$ ) either at atmospheric pressure (AP_CS samples, $\mathrm{n}=9$ ) or at $50 \mathrm{MPa}\left(\mathrm{HP} \_\mathrm{CS}\right.$ samples, $\mathrm{n}=9$ ). Results are expressed as the mean \pm the standard error. Different letters in the same row indicate significant differences between means $(p<0.05)$.

\begin{tabular}{lccc}
\hline & Day 0 & \multicolumn{3}{c}{ Day 12 } \\
\cline { 2 - 4 } & C & AP_CS & HP_CS \\
\hline Total viable bacteria & $4.0 \pm 0.2 \mathrm{a}$ & $6.2 \pm 0.2 \mathrm{~b}$ & $3.4 \pm 0.1 \mathrm{a}$ \\
$\mathrm{H}_{2}$ S-producing organisms & $3.2 \pm 0.3 \mathrm{~b}$ & $6.3 \pm 0.1 \mathrm{C}$ & $<1 \mathrm{a}$ \\
Luminiscent colonies & $<2 \mathrm{a}$ & $4.1 \pm 0.8 \mathrm{~b}$ & $<2 \mathrm{a}$ \\
Total aerobic mesophiles & $4.8 \pm 0.1 \mathrm{~b}$ & $6.4 \pm 0.2 \mathrm{c}$ & $4.2 \pm 0.1 \mathrm{a}$ \\
Pseudomonas spp. & $3.9 \pm 0.2 \mathrm{a}$ & $5.1 \pm 0.2 \mathrm{~b}$ & $3.1 \pm 0.3 \mathrm{a}$ \\
Lactic acid bacteria & $2.4 \pm 0.1 \mathrm{a}$ & $4.1 \pm 0.2 \mathrm{~b}$ & $2.3 \pm 0.1 \mathrm{a}$ \\
Enterobacteria & $2.2 \pm 0.1 \mathrm{~b}$ & $4.7 \pm 0.4 \mathrm{c}$ & $<1 \mathrm{a}$ \\
Sulphite-reducing bacteria & $<1 \mathrm{a}$ & $4.2 \pm 0.2 *$ & $<1 \mathrm{a}$ \\
\hline
\end{tabular}

*Just in one experiment $(n=3)$. In the other two replicated experiments $(n=6)$, sulphite-reducing microorganisms remained under the detection limit. 
TABLE 2 Polymerization and hydrolytic compounds ( $\mathrm{g} / 100 \mathrm{~g}$ extracted lipids) \pm standard error values in mackerel fillets before ( $C$ samples, $n=9)$ and after 12 days of cold storage $\left(5^{\circ} \mathrm{C}\right.$ ) either at atmospheric pressure (AP_CS samples, $n=9$ ) or at $50 \mathrm{MPa}$ (HP_CS samples, $\mathrm{n}=9$ ). Different letters in the same row indicate significant differences between means $(p<0.05)$.

\begin{tabular}{lccc}
\hline & Day 0 & \multicolumn{2}{c}{ Day 12 } \\
\cline { 2 - 4 } & C & AP_CS & HP_CS \\
\hline Polymerization compounds & $3.2 \pm 0.7 \mathrm{a}$ & $2.6 \pm 0.6 \mathrm{a}$ & $3.7 \pm 0.9 \mathrm{a}$ \\
Hydrolytic compounds & $16.5 \pm 5.0 \mathrm{a}$ & $64.7 \pm 10.8 \mathrm{~b}$ & $28.5 \pm 6.8 \mathrm{a}$ \\
\hline
\end{tabular}


TABLE 3 Summary of the fatty acid methyl ester (FAME) composition ( $\mathrm{g} / 100 \mathrm{~g}$ extracted lipids) and polyene index \pm standard error values in mackerel fillets before ( $C$ samples, $n=9$ ) and after 12 days of cold storage $\left(5^{\circ} \mathrm{C}\right)$ either at atmospheric pressure (AP_CS samples, $n=9$ ) or at $50 \mathrm{MPa}\left(\mathrm{HP} \_C S\right.$ samples, $n=9$ ).

\begin{tabular}{lrrr}
\hline \multirow{2}{*}{ FAME } & \multicolumn{1}{c}{ Day 0 } & \multicolumn{2}{c}{ Day 12 } \\
\cline { 2 - 4 } & \multicolumn{1}{c}{ C } & \multicolumn{1}{c}{ AP_CS } & HP_CS \\
\hline SFA & $27.9 \pm 2.9$ & $30.5 \pm 2.4$ & $24.4 \pm 2.5$ \\
MUFA & $22.7 \pm 3.5$ & $25.8 \pm 3.2$ & $26.6 \pm 3.2$ \\
PUFA & $38.3 \pm 2.4$ & $32.2 \pm 3.7$ & $39.1 \pm 3.9$ \\
\hline EPA+DHA & $32.2 \pm 2.3$ & $28.2 \pm 3.8$ & $33.4 \pm 3.2$ \\
Polyene index & $1.8 \pm 0.2$ & $1.6 \pm 0.8$ & $2.1 \pm 0.6$ \\
\hline
\end{tabular}

SFA: saturated fatty acids; MUFA: monounsaturated fatty acids; PUFA: polyunsaturated fatty acids; EPA: eicosapentanoic acid; DHA: docosahexanoic acid. 
TABLE 4 Mean protein solubility $(\mathrm{g} / 100 \mathrm{~g}) \pm$ standard error values in mackerel fillets before ( $C$ samples, $n=9$ ) and after 12 days of cold storage $\left(5^{\circ} \mathrm{C}\right.$ ) either at atmospheric pressure (AP_CS samples, $\mathrm{n}=9$ ) or at $50 \mathrm{MPa}$ (HP_CS samples, $n=9$ ). Different letters in the same row indicate significant differences between means $(p<0.05)$.

Day 0

Day 7

C

AP_CS

HP_CS

Sarcoplasmic proteins

$2.37 \pm 0.18$ a

$2.27 \pm 0.17$ a

$0.81 \pm 0.07 \mathrm{~b}$

Myofibrillar proteins

$7.47 \pm 0.23$ a

$3.18 \pm 0.56 \mathrm{~b}$

$2.04 \pm 0.23 b$

Innovative Food Science and Emerging Technologies 51 (2019) 41-50 
TABLE 5 Mean \pm standard error values of the fish-quality indicators in mackerel fillets before ( $C$ samples, $n=9$ ) and after 12 days of cold storage $\left(5^{\circ} \mathrm{C}\right)$ either at atmospheric pressure (AP_CS samples, $n=9$ ) or at $50 \mathrm{MPa}$ (HP_CS samples, $n=9$ ). Different letters in the same row indicate significant differences between means $(p<0.05)$.

\begin{tabular}{lccc}
\hline & Day 0 & \multicolumn{3}{c}{ Day 12 } \\
\cline { 2 - 4 } & C & AP_CS & HP_CS \\
\hline Before cooking & & & \\
\hline pH & $6.20 \pm 0.03 \mathrm{a}$ & $6.54 \pm 0.04 \mathrm{c}$ & $6.31 \pm 0.04 \mathrm{~b}$ \\
TVB-N & $11.89 \pm 0.56 \mathrm{a}$ & $63.77 \pm 2.52 \mathrm{c}$ & $17.62 \pm 0.52 \mathrm{~b}$ \\
Drip loss & - & $3.77 \pm 0.23 \mathrm{a}$ & $2.87 \pm 0.30 \mathrm{~b}$ \\
Water holding capacity & $80.31 \pm 0.52 \mathrm{a}$ & $69.92 \pm 0.81 \mathrm{c}$ & $77.20 \pm 1.12 \mathrm{~b}$ \\
Hardness & $44.38 \pm 2.62 \mathrm{a}$ & $42.96 \pm 2.39 \mathrm{a}$ & $36.53 \pm 2.36 \mathrm{a}$ \\
$\mathrm{L}$ & $41.16 \pm 0.60 \mathrm{a}$ & $46.70 \pm 0.48 \mathrm{~b}$ & $46.53 \pm 0.34 \mathrm{~b}$ \\
$\mathrm{a}$ & $-0.87 \pm 0.39 \mathrm{a}$ & $-0.48 \pm 0.35 \mathrm{a}$ & $-0.98 \pm 0.32 \mathrm{a}$ \\
$\mathrm{b}$ & $4.38 \pm 0.45 \mathrm{a}$ & $6.24 \pm 0.41 \mathrm{~b}$ & $7.53 \pm 0.55 \mathrm{~b}$ \\
$\Delta \mathrm{E}$ & -- & $6.17 \pm 0.54 \mathrm{a}$ & $6.41 \pm 0.77 \mathrm{a}$ \\
& & & \\
After cooking & & & \\
\hline Cooking loss & $15.72 \pm 0.63 \mathrm{a}$ & $14.96 \pm 0.60 \mathrm{a}$ & $14.43 \pm 0.63 \mathrm{a}$ \\
Hardness & $18.66 \pm 1.06 \mathrm{a}$ & $24.20 \pm 1.10 \mathrm{~b}$ & $20.61 \pm 0.67 \mathrm{a}$ \\
$\mathrm{L}$ & $62.33 \pm 0.90 \mathrm{a}$ & $62.62 \pm 0.68 \mathrm{a}$ & $62.99 \pm 0.64 \mathrm{a}$ \\
$\mathrm{a}$ & $-0.07 \pm 0.30 \mathrm{a}$ & $-0.07 \pm 0.38 \mathrm{a}$ & $-1.07 \pm 0.23 \mathrm{a}$ \\
$\mathrm{b}$ & $13.68 \pm 0.41 \mathrm{a}$ & $10.38 \pm 0.35 \mathrm{~b}$ & $10.70 \pm 0.40 \mathrm{~b}$ \\
$\Delta$ E & -- & $3.86 \pm 0.16 \mathrm{a}$ & $3.66 \pm 0.51 \mathrm{a}$ \\
\hline
\end{tabular}




\section{FIGURE CAPTIONS}

Figure 1 HPSEC chromatograms of lipids extracted from mackerel fillets before (C samples) and after 12 days of cold storage $\left(5{ }^{\circ} \mathrm{C}\right)$ either at atmospheric pressure (AP_CS samples) or at $50 \mathrm{MPa}$ (HP_CS samples). Peaks in order of retention times: (1) polymerization compounds; (2) triacylglycerols; (3+4) hydrolytic compounds (3: diacylglycerols and 4: monoacylglycerols plus free fatty acids).

Figure 2 1D SDS-PAGE protein profiles of water- and salt-soluble proteins extracted from mackerel fillets before (C samples) and after 12 days of cold storage $\left(5^{\circ} \mathrm{C}\right)$ either at atmospheric pressure (AP_CS samples) or at $50 \mathrm{MPa}$ (HP_CS samples). Molecular weight of standard proteins (S) is indicated in $\mathrm{kDa}$. 
FIGURE 1
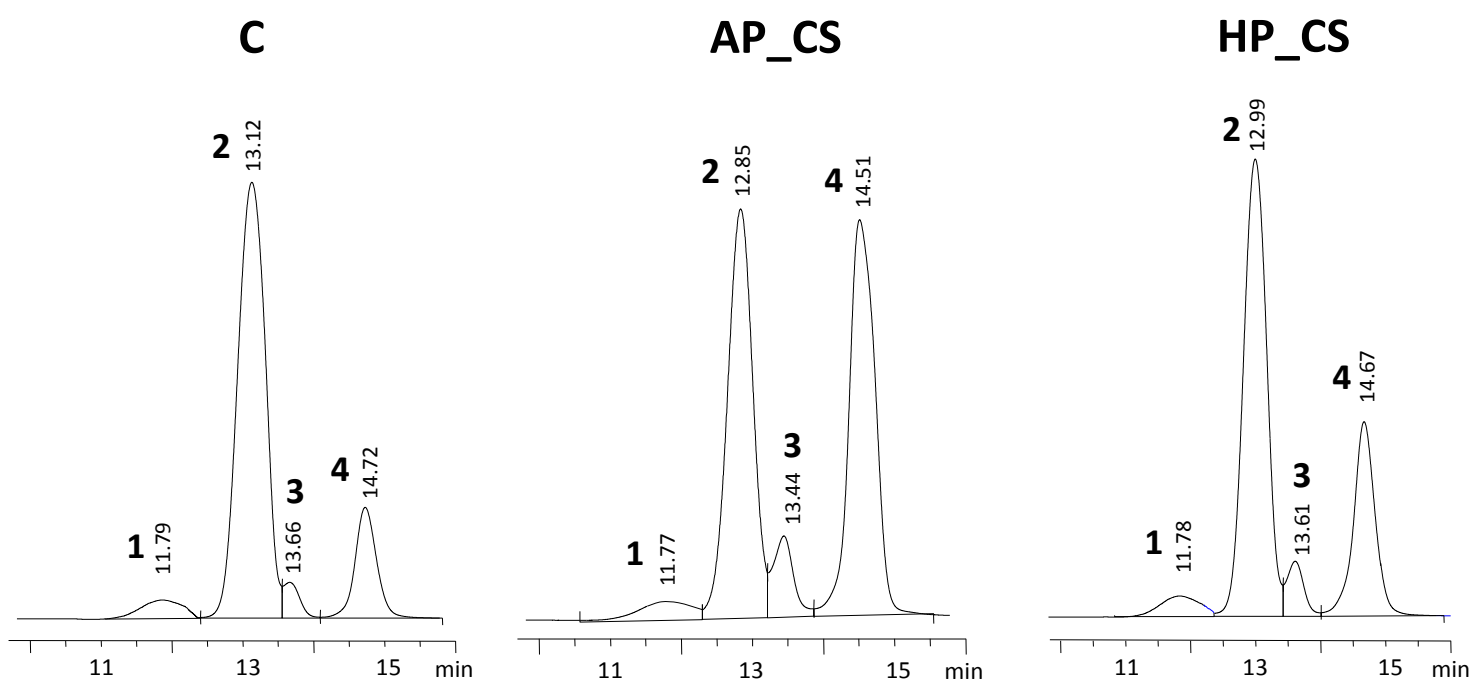

Innovative Food Science and Emerging Technologies 51 (2019) 41-50 


\section{FIGURE 2}

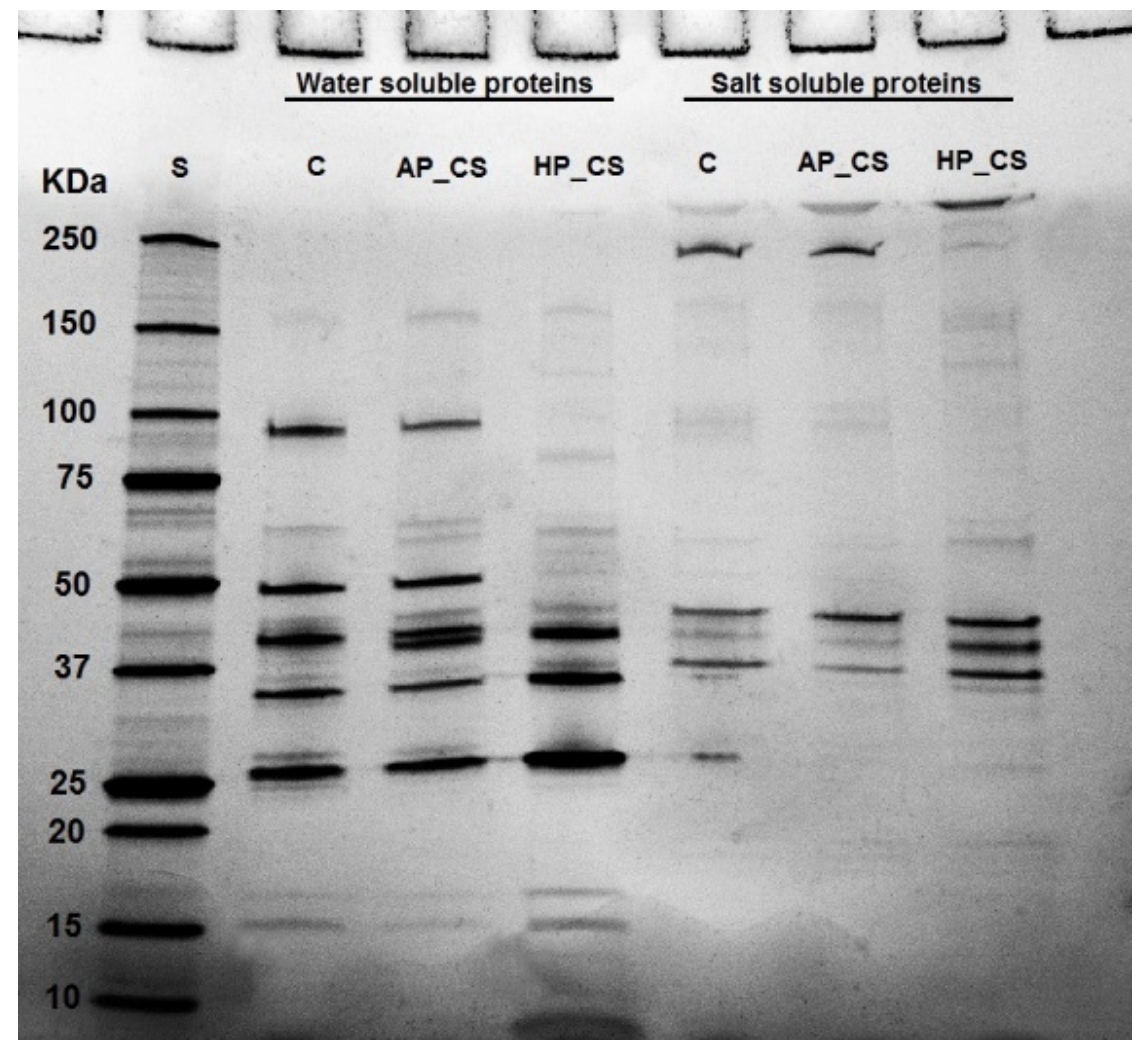

Innovative Food Science and Emerging Technologies 51 (2019) 41-50 